\title{
STRATEGIES AND ROLE OF LOCAL GOVERNMENT IN IMPROVING THE COMPETITIVENESS OF TRADITIONAL FISHERMEN IN PANDEGLANG, BANTEN
}

\author{
Kusumajanti ${ }^{\star 1}$, Ni Putu Eka Widiastuti²), Asep Kamaluddin ${ }^{3)}$ \\ 1) Communication Department, UPN "Veteran" Jakarta \\ 2) Accounting Departement, UPN "Veteran" Jakarta \\ 3) International Relation Department, UPN "Veteran" Jakarta
}

Manuscript accepted on 11-23-2019, revised 11-24-2019, approved 11-26-2019

\begin{abstract}
The aims of study to explore in depth: a. strategies and role of local government supports the formation of fishermen groups and group performance in enhancing the competitiveness of traditional fishermen; b. Strategies undertaken by local governments to improve competitiveness so as to realize the prosperity of traditional fishermen, c. group communication model between local government, traditional fishermen group, and partners This study use qualitative research methods with a critical paradigm referring to the critical concepts of Marxist thought. The results showed that the government through the Ministry of Marine Affairs and Fisheries Republic of Indonesia has issued Government Regulation no. 50 Year 2015 on empowering small fishermen and small fish farmers. The Ministry of Marine Affairs and Fisheries has an agenda to improve the welfare of traditional fishermen and to optimize their potentials in groups, which are handed down to the provincial and district fisheries departments. Pandeglang District Government as the object of research through Fisheries Department has the authority to manage, utilize, and conserve marine and fishery resources for the welfare of Pandeglang community, especially fisherman community, cultivation, processing and marketing of fish, and to increase contribution for PAD (District Owned Revenue). Fisheries Department develop strategies for improving the welfare of traditional fishermen, among others, encourage the formation of fishermen cooperatives with legal status. Socialization of the use of fishing gear which is not prohibited by the government. This is because there are still many traditional fishermen in Pandeglang who use Cantrang that can threaten the sustainability of marine ecosystems. The local government through related offices has not been actively involved in providing assistance to traditional fishermen so that they have high competitiveness such as maintaining good quality fish quality, stable catch quantity, environment of fishery and marine areas that is maintained so as to ensure the sustainability of existence fish in the sea. The results of this study have implications on the preparation of roles and strategies of local governments in improving the competitiveness of traditional fishermen adapted to local elements so that traditional fishermen become prosperous.
\end{abstract}

Keywords: Strategy, The role of local government, traditional fishermen, fishermen cooperatives 


\section{INTRODUCTION}

Indonesia which is famous as a maritime country has enormous marine potential. Two third of Indonesia's total area of 5.8 million square kilometers consist of sea and water with a coastline of about 97 thousand kilometers. This vast sea area is an opportunity to be developed into businesses in various sectors. Minister of Marine Affairs and Fisheries, Susi Pudjiastuti stated that many resource-based businesses potential can become promising opportunities, such as marine, fishery, tourism, processed industries, marine service industries and other environmentally friendly industries. ${ }^{1}$

Indonesia's territory stretches along 3,977 miles from the Indonesian Ocean to the Pacific Ocean. As a whole Indonesia has an ocean consisting of about 3,273,810 km2 (square kilometers) $)^{2}$. The boundary of Indonesian sea territory according to international sea law, namely based on the sea territorial is along 12 nautical miles and the exclusive economic zone of the 200 nautical miles (in the same direction with the direction of the wind). Indonesia's vast oceans should bring blessing to the Indonesian nation. Natural resources contained in the oceans are numerous and this can be used for the welfare of the Indonesian nation.

Indonesia is an archipelagic country consisting of large and small islands. Large islands include Papua Island with an area of $785,753 \mathrm{~km}^{2}$, Kalimantan Island with an area of 748,168 $\mathrm{km}^{2}$, Sumatra Island with an area of $443,066 \mathrm{~km}^{2}$, Sulawesi Island with an area of $180,681 \mathrm{~km}^{2}$, Java Island with an area of $138,794 \mathrm{~km}^{2}$, Timor Island with an area of $28,418 \mathrm{~km}^{2}$, Halmahera Island with an area of $18,040 \mathrm{~km}^{2}$, Seram Island with an area of $17,454 \mathrm{~km}^{2}$, Sumbawa Island with an area of $14,386 \mathrm{~km}^{2}$, Flores Island with an area of $14,154 \mathrm{~km}^{2}$, and other large islands. Based on data the number of population that inhabits the five largest islands in Indonesia region are as follows:

Table 1. Data on Comparison of Total Area of the Island with Total Population

\begin{tabular}{lccc}
\multicolumn{1}{c}{ Island } & Total Area & Population & Comparison \\
\hline Irian/Papua & $785,753 \mathrm{~km}^{2}$ & $3,593,903$ people & $1: 4.6$ \\
\hline Kalimantan & $748,163 \mathrm{~km}^{2}$ & $13,787,831$ people & $1: 18.4$ \\
\hline Sumatra & $443,066 \mathrm{~km}^{2}$ & $50,630,931$ people & $1: 114.3$ \\
\hline Sulawesi & $180,681 \mathrm{~km}^{2}$ & $17,371,782$ people & $1: 96.14$ \\
\hline Jawa & $138,794 \mathrm{~km}^{2}$ & $136,610,590$ people & $1: 984.3$
\end{tabular}

Source: BPS Census of 2010

Table 1 illustrates occupancy rates in each of these islands and the ratio of population density to the area of the island. The data is related to the idea that the density of the population in a region has an impact on the economic level of its population.

This large marine potential can be utilized by various elements of Indonesian society including the main actors, namely fishermen. In Indonesia, the number of traditional fishermen (nelayan tangkap) was recorded at 2.2 million people (Ministry of Marine Affairs and Fisheries, 2012). Based on this figure, more than 95 percent were categorized as traditional fishermen. Mostly traditional economic actors, fishing gear, and production capital used by traditional fishermen are by and large still simple / limited. Various policies have been issued by the Government of Indonesia in order to support the empowerment of fishermen, especially traditional fishermen. The Government of Indonesia issued Government Regulation Number 50 of 2015 on the Empowerment of Small Fishermen and Small Fish Cultivators. The Government of Indonesia through the Ministry of Marine Affairs and Fisheries plans to improve the welfare of small fishermen and optimize their potential in groups. Small Fisherman is a person whose livelihood is fishing to meet the daily needs by using a fishing vessel with the largest size of 5 (five) gross tons (GT). The empowerment of small fishermen can be done with various efforts to

\footnotetext{
${ }^{1}$ Press Release of the Bureau of Inter-government Agency Cooperation and PR of the Ministry of Marine and Fisheryof the Republic of Indonesia, 13 November 2015 No: 079/SJ.6/HM.310/X/2015. Potential of Indonesia Sea Sector is Promising.
} 
improve the ability of Small Fishermen. They are even given the opportunity to do Small Fish Farming so they can carry out their activities better.

The results of the census conducted by the Central Bureau of Statistics showed that in 2015 the number of traditional fishermen has decreased from about 1.6 million households to 364 thousand households, and on the contrary there is an increase in the number of small scale fish farmers from 85,000 to 1.2 million households. Responding to the results of the census, the Minister of Marine Affairs and Fisheries admitted that it was surprised to know the decrease in the number of traditional fishermen in Indonesia.

Taking these conditions into account, this study was intended to explore as much information as possible about the existence of traditional fishermen, especially those operating on the coast of Java Island. Each local government should have an opportunity to overcome the decline in the number of traditional fishermen and implement the (Central) government regulations into the rules of the regional governments. The local government's support to small fishermen is desirable towards fishermen in order to allow them to compete with large fishermen despite limited ability of the ship they own. The capability of small fishing vessels is understably less than the catching capacity of a large fisherman with large cruising capability and capture capacity. Types of nets that may be used (by small fishermen) is in accordance with the regulation which is intended that small fish are not netted so that fish breeding can be optimized. The central and local governments have great attention on the small fishermen. Small fishing businesses are not left alone. They were guided to run their business in groups and their skills and knowledge were enhanced through the provision of trainings and fishing credit. If up until now these small-scale fishermen go to sea and directly sell their catch individually in the future government wants them to be incorporated in groups of fishermen.

to: ${ }^{2}$

Empowerment of Small Fishermen and Small Fish Cultivators in the group was designed

a. realize the independence of Small Fishermen and Small Fish Farmers in order to improve the welfare, quality, and standard of living;

b. improve Small Fishermen and Small Fish Farmers into productive, efficient, value-added, and sustainable business;

c. improve the capacity of Small Fishermen and Small Fish Farmers;

d. to ensure access of Small Fishermen and Small Fish Farmers to fish resources and the environment, technology, capital, production infrastructure, and marketing; and

e. increase the growth of small fishermen groups and small fish farmer groups.

Empowerment referred to in paragraph (1) shall be granted to: a. Small Fishermen; and b. Small Cultivators (Farmers) who meet the following criteria: 1. using simple technology; and 2. conducting fish farming with the total area: a) fish farming business in fresh water for activities: 1) fish hatchery of the maximum of 0.75 ha; and 2) the largest fish cultivation of 2 ha (two hectares); b) brackish fish water cultivation for activities: 1) the largest fish hatchery of 0.5 ha (half hectare); and 2) the largest fish enlargement of 5 ha (five hectares); c) fish breeding business in seawater for activities: 1) the largest fish hatchery of 0.5 ha (half hectare); and 2) the largest fish enlargement 2 ha (two hectares).

The empowerment of small fishermen groups becomes the most important thing so that they can improve their own ability together with partners such as fishery business actors. Cooperation in fisheries management in the framework of Empowering Small Fishermen and Small-Scaled Cultivators can be done through the approach of the power of networking of business actors and resources that consider the equality aspect of proportional effort in business. Thus, in the future it will never happen again small fishermen feeling disadvantaged, especially by the middlemen. Such practices was actually caused by small fishermen having no bargaining power over their catch. The poverty has rendered them powerless by the offering a

\footnotetext{
${ }^{2}$ Government Regulation No 50 of 2015on EMPOWERMENT OF SMALL FISHERMEN AND SMALL FISH CULTIVATORS (FARMERS) Article 2
} 
low price, while their catch is very limited due to the limitedness of the coverage of the ship, and the number of fish they usually can catch.

Observing this condition it is very necessary to conduct in-depth research related to the support of local governments in improving the competitiveness of traditional fishermen. Fishermen on the southern coast of Java Island, especially in Pandeglang Regency as the object of research with the following considerations:

a. fishermen squeezed by modernization and rapid development activities including tourism development.

b. Traditional fishermen are vulnerable to change professions due to poverty.

The results of this study were expected to give an in-depth insight and answer the following questions:

a. What is the strategy undertaken by local governments to improve the welfare of traditional fishermen or small fishermen?

b. How is the role of the local governments in supporting the formation of fishing groups and group performance in improving the welfare of group members?

c. What is the model of group communication carried out by the local government with traditional fishermen groups, among fellow fishermen group members, between fishermen groups and their partners taking into consideration the cultural factors and local elements of the local community?

This research was expected to obtain the following findings:

a. Strategies undertaken by the local governments to maintain the number of traditional fishermen and improve the welfare of fishermen in their region.

b. Mapping the role of local government in supporting the formation of fishermen groups and group performance in improving the welfare of group members.

c. Creating a model of group communication conducted by the local government with traditional fishermen groups, among fellow fishermen group members, between groups of fishermen with their partners taking into account the cultural factors and local community elements.

\section{RESEARCH METHOD}

This study used a critical theory paradigm to answer all problems related to the strategy of local governments in improving the competitiveness of traditional fishermen in the coastal area of Java Island. The use of this paradigm was intended to affirm an ontology based on historical realism that Indonesia is known as a maritime country with a formidable fishing force. From the epistemology it is transactional, and from methodology it is a dialogical and dialectical.

This research sought to produce a fisherman's transformation. The cause of the decline in the number of traditional fishermen was based on data unveiled by BPS published in the Press Release of the Ministry of Marine Affairs and Fisheries dated on November 13, 2015. The critical paradigm was used to dig the external and internal elements that will direct the change of the previously known form through certain processes ${ }^{3}$ such as the support gained by fishermen from their local governments so that they can sustain their life as fishermen. The process of transformation in the social order of a traditional fisherman can be driven by the demand for a better standard of living or they are trying to get out of poverty. This is because traditional fishermen are very close to poverty. ${ }^{4}$ Lifestyle changes and technological developments can also be factors that cause a transformation. The result of research is a historical and structural knowledge about the strategies used by both central and regional governments to strengthen the competitiveness level of traditional fishermen. These are assessed according to the

\footnotetext{
${ }^{3}$ Guba, E.G., 1990, The Alternative Paradigm Dialog in E.G. Guba (Ed.) The Paradigm Dialog, Newbury Park, CA: Sage, page 17-30

${ }^{4}$ Imron, Masyhuri , 2003, Povery in the Fshermen Community in Jurnal Masyarakat dan Budaya, Volume 5 No. 1 , page $63-84$
} 
historical position of fishermen and legislation that support or even weaken position of traditional fishermen, and the ability of a government regulation to produce praxis, or action.

The qualitative research was used to explore in depth various strategies undertaken by the local government in an effort to improve the competitiveness of traditional/ small fishermen. Qualitative research is able to explore the efforts made by members of fisherfolk groups to have the competitiveness against large-scale fishermen, even the efforts made to get them out of various economic problems.

The collection of data was done by determining people who will become key informants in this research. As for the key informants include officials of the Fisheries Office in each area of the research object, namely the Fisheries Office of Pandeglang Regency, and Pangandaran Regency. Data was also collected from fishermen who are members of Village Unit Cooperative, with consideration, they can give in depth explanation on various strategies that have been done by local government in this case the Fishery and Maritime Office of the District (Regency).

\section{RESEARCH RESULTS AND DISCUSSION}

The life of fishermen, especially the traditional fishermen in the Indonesian territory to date has always showed a trend of decline, with the use of boats with the largest size of 5 (five) gross tons (GT). The operation of ships of this size are not too promising to help increase income of fishermen. Moreover most fishermen think that the most important for them is to go to sea so that they can fulfil their household needs.

This research sought to explore in depth the various strategies undertaken by the local governments as a form of support to fishermen to improve the competitiveness and level of the fishermen's economy. This study also found various models of group communication conducted by the actors of communication namely the Fisheries Office, fishermen, buyers / fishermen partners.

\section{Strategy of Pandeglang Regency Government in Maintaining the Number of Traditional Fishermen and Improving Fishermen's Welfare in their Area}

Pandeglang Regency is about $110 \mathrm{~km}$ from Jakarta, with distance of about three (3) hours by car. Pandeglang is renowned for its many beach destinations such as Anyer Beach, Carita Beach, Tanjung Lesung, Ujung Kulon's famous tourist attraction with the Badak Bercula One Wildlife Sanctuary, as well as other tourist attractions.

The maritime potential of Pandeglang Regency is very promising, marked by the average fishery production rate of 44,000 tons in 2016 . The number of fishermen in Pandeglang Regency was registered at 12,500 people, and supported by 14 units of fish auction places (TPI). Some of its fishery products were sent to Jakarta to meet the needs of the people of Jakarta.

Potential of Marine and Fisheries in Pandeglang Regency as per 2016:

a. Number of traditional fishermen (nelayan tangkap) as many as 12,500 people

b. People involved in aquaculture sector as many as 4,979

c. Processors and marketers of fish catch and cultivation were recorded at 5,724 people

d. 50 salt farmers

e. Community groups work as marine and fishery control group as many as 100 people

f. The number of processing units with the scale of household as many as 10,000 units

g. The number of ships/ boats $>10 \mathrm{GT}$ as many as 1,472 units

h. Number of fish auction places (TPI) were recorded at14 units

i. The regency has 33 small islands

j. Having a 150 hectare area for floating net and cage

k. Fishery production catch of 44,000 tons / year

I. Production of aquaculture at 11,500 tons / year 
Pandeglang Regency Fishery Office has a duty to carry out the tasks of local government in the field of fishery based on the principle of autonomy and other supporting tasks. The Fisheries Office in accordance with its tasks is authorized to manage, utilize, and conserve marine and fishery resources for the welfare of the Pandeglang community, in particular the fishing communities, cultivators, processors and fish marketers, and to increase contributions to the Originally Earned Local Revenue (PAD).

Pandeglang regency as one of the regencies in Banten province has prime commodity of marine and fishery. Working motivation of fishermen and fish farmers to work is very high, but they were still constrained by fishing gear. Many fishermen in Panimbang Jaya Sub-district, for example, still use fishing gear from the type that is prohibited by the government, such as Cantrang or Pukat Tarik (trawl). Ministerial Regulation No. 2 of 2015 concerning the Prohibition of the use of trawl and seine nets was officially effective on January 1,2017. With the enforcement of the regulation, all fishing gear used by Indonesian fishing vessels (KII) and others included in the group, it is prohibited. Nevertheless, many fishermen still use these fishing gears.

Various efforts undertaken by the Fisheries Office of Pandeglang Regency for the enforcement of ministerial regulation No 2 of 2015 on the use of fishing gear as follows:

1. Socialization on the impact of the use of Pukat / Cantrang fishing gear on the sustainability of fish availability in Pandeglang Regency

2. Establishing a Exchange Post of Fishing Equipment

3. Together with the Marine Police conduct raids and arrests of fishing boats still using illegal fishing gear such as Cantrang

In the year 2017, the Fisheries Office made plans for the provision of assistance of fishing gear and other needs for fishermen. This assistance scheme was intended to increase the amount of catches to meet market needs. In addition, the Office also planned to provide fishing gear, build ship workshops, procurement of Ting-Ting boats, Outboard motor for boats, and fish processing equipment to be undertaken by fishermen's wives.

Pandeglang District Fishery Office as an arm of the Ministry of Marine Affairs and Fisheries gave an aid in the form of fishing gear to fishermen to replace the common fishing equipment of Cantrang / Sodong. Cantrang fishing equipment is prohibited to be used to catch fish in all parts of Indonesia based on the Ministry of Marine and Fishery Regulation No. 2 I PERMEN-KP / 2015 and Number 71 / PERMEN-KP / 2016. The fishermen were given the opportunity to change their fishing gear before January 1, 2018. As for the reason the government to prohibit the use of fishing gear, trawl, seine nets because they were considered to create problems and damage the sustainability of fish resources, namely:

a. threatening the extinction of marine biota,

b. resulting in the destruction of the habitat, and

c. endanger the safety of users / fishermen.

The fishermen have been using fishing equipment type of puta / cantrang / sodong for generations and now feel the impact of the difficulty to catch fish in the waters around Pandeglang because of insufficient numbers of fish. This reality is acknowledged by Mr. Az from Panimbang Jaya Village, "It is now difficult to get fish around Pandeglang so that we have no choice but to go to areas closest to Ujung Kulon, or Krakatau (Krakatoa)". The difficulty to get fish was caused by the use of fishing gear / cantrang / sodong by fishermen to catch fish that resulted in the catch all marine biota not only big fish. Small fish, and even coral become damaged. Small fish incidentally caught by the nets will eventually be thrown into the sea by the fishermen because it will only become garbage and fill the ship. They are also less marketable. The survival of marine life can be well protected if the fishermen do not use the fishing gear. Small fish have the chance to live up to become big, coral reefs are well preserved so it becomes a place for fish to breed.

The Pandeglang District Fishery Office found it quite difficult to build the awareness of fishermen on the impact of using of illegal fishing gear and persuade them to switch to fishing gear permitted by the government. As a follow-up of the appeal, the Fisheries Office has done socialization on the use of fishing gear and its impact on the sustainability of marine biota and 
the availability of fish in the sea. Fishermen were informed of the negative impacts of using trawlers. Mr. Az explained the advantage and disadvatage of using a fishing gear,

"Catching fish using sodong / pukat (trawlers) can quickly produce results and big catch. Fishermen also do not need to stay at the sea. Leaving in the morning we return home in the afternoon bringing the results of the catch. We even can return home faster if we are lucky enough to find the point of fish gathering". Not like before now we find it difficult to find fish around the beach. If we catch fish in the areas up to Ujung Kulon it is usually prohibited by the government and marine police because it is declared as a nature conservation area. In order to get a lot of fish we should go to Lampung region, but the fish should be sold in Lampung. The catch could not be brought to Pandeglang ".

Mr. DD also admitted that fishermen currently found difficulty to catch fish in the waters of Pandeglang. Fishermen in Sidamukti Village who now all have been using fishing gear allowed by the government feel that it is very different from using regular net. They had to spread the net first at a point and pulled them on the next day. Thus they must spend the night in the sea meaning that they have to bring sufficient logistics supplies to meet their needs. In addition, they should always be vigilant that their boats and nets are not carried away into prohibited areas such as nature conservation areas, the territorial waters of the Indonesian Navy, or areas managed by private companies. If this happens then they have to deal with the marine security apparatus which may result in their detention. If fishermen do not want to be arrested then it is no secret that those caught have to pay some money.

Local governments continue to strive to ensure that traditional fishermen no longer find the difficulties to catch fish in Pandeglang District. The Fisheries Office in the future are trying to make fish rumpon so that the sustainability of the existence of fish can be maintained properly. But it is acknowledged by Mr. Ad, the Division Head of Fisheries, that it is not an easy thing to build fish rumpon in the sea. This is mostly due to the dense traffic around Pandeglang District, such the heavy traffic of ferries travelling from Merak to Bakauhuni, Lampung and vice versa.

Strategies undertaken by the local government of Pandeglang Regency in this case the Fisheries Office is felt already by traditional fishermen in their favours. Efforts to increase the number of catch fish have been done by the Fisheries Office in cooperation with related agencies. Various parties have to work together to increase the level of welfare of fishermen, such as through cooperation among related government agencies. The Fisheries Office is the agency most responsible for increasing the competitiveness of traditional fishermen assisted by the Office of Cooperatives, and Office of Women Empowerment, especially for the fishermen's wives to process the seafood into food products.

The improvement in the level of fishermen welfare could lead to an increase in the number and skill of fishermen. Everyone will be interested in becoming a fisherman, not other jobs. A strong economic level will increase the bargaining power of a fisherman on all his catch. Until now fishermen in Pandeglang are still mired in the debt trap set up by the moneylenders who also work as ship merchants. In the future, the fishermen can take advantage the strength of their group to manage the Fish Auction Place as a legal channel for fish sales. The needs of consumers for fish in the Pandeglang area such as hotels and restaurants can be met by local fishermen. Thus, prospective buyers no longer have to buy fish from Jakarta. This condition has a direct effect on the fishermen and the increase in locally earned revenue (PAD) of Pandeglang Regency.

\section{The Role of Regional Government in Supporting the Formation of Fishermen Group and Group Performance in Improving the Welfare of Group Members}

Pandeglang Regency Government in this case the Fisheries Office has conducted various strategies to improve the welfare of fishermen. The results have been felt by the fishermen whereby all efforts undertaken by the agency is beneficial to the fishermen, namely efforts to improve the quality and quantity of the economy and social of the fishermen. Mr. DD as one of the leaders and managers of Fisherman Cooperative Mina Bahari Sidamukti Village said that the condition of fishermen was in dismal state, "What is said by Mr. Adr from the 
Fisheries Office is true. (Most)... traditional fishermen do not have the capital to go to sea. They are forced to borrow money from Langgan / Bakul / Tengkulak (middlemen) which will be deducted or paid back with results of their catch ".

Mr. DD further illustrated,

"the fate experienced by the fishermen if they borrow money from the Langgan/Bakul (middlemen) to meet their needs for the diesel fuel. Fishermen bought diesel fuel at the price of Rp. 7,000 / liter (from middlemen) while in the market the price is only Rp. 5,500 I liter. Besides that fishermen also have to borrow money to buy logistics needs such as rice, side dishes, and cigarettes to fulfill their needs for a week in the sea. The results of the catch should be sold to the Langgan/Bakul but the price is usually below the market price. Then fishermen's income still have to be cut $10 \%$ to pay for government levies to be used as originally earned revenue (PAD), and Langgan. This is the fate of fishermen. They have to buy logistics needs in high price but sell their fish catch in low price ".

Taking this condition into consideration, the Pandeglang Regency Fisheries Office created a plan to form fishery groups, which the office then encouraged to form fishery cooperatives under the auspices of the Fisheries Office and the Cooperative Office. Until now two Cooperative Mina Bahari Cooperative have been formed. The two are Cooperative Panimbang Bahari Lestari and one cooperative in the Sub-District of Labuan which is still the administrative process in the Cooperatives Office.

Another limitation noted by the Pandeglang District Fishery Office is the limited capital faced by the traditional fishermen in the region. This relates to the economic ability of fishermen to prepare to go to sea for about five (5) days, in which at least they have to prepare logistics such as diesel fuel, foodstuff, and money for their family at home. On average they should have a capital of about 2 - 3 million rupiahs. If they do not have the capital to go to sea then they will have to borrow money from Bakul or middleman. The fishermen will return the money under an agreement that the result of their catch must be sold to Bakul even though the price offered is much lower than the market price. This situation has been going on for years.

The Fisheries Office concentrated on the formation of fishermen cooperatives with the aim the fishermen can work hand in hand in strengthening the traditional fishermen's economy. Cooperatives can provide:

1. Capital to go to sea

2. Fishing gears

3. Fuel

4. Workshop for ship engines

5. Household and basic needs

6. Savings and loan for members

7. Managing Fish Auction Places

Another strategy undertaken by local governments to improve the competitiveness of fishermen so that they can compete with fishermen from other regions is to strengthen the traditional fishing economy. These programs and activities are related to the potential of marine and aquaculture fisheries that must be carefully planned so that it can be done in synergy with other development programs such as cooperative development, which will also increase originally earned local revenue (PAD) of Pandeglang Regency. This program is managed by the local government with the main aim to improve traditional fishermen's economy so that they have the ability to compete with fishermen from other regions. Thus, the implementation of marine and fishery programs should be continuously strengthened through continuous integration and coordination among agencies under the local government of Pandeglang Regency. 


\section{Group Communication Model Between Local Government, Traditional Fishermen Group, and Partners}

The local government of Pandeglang District maintains direct communication with fishermen in the region through the Fisheries Department put strategy into effect: enhancing the competitiveness of traditional fishermen. Fisheries Department relate directly between the fishermen either individually or in groups in socialization, and mentoring. Communication Fisheries Department activity is transactional, where the process of sending messages between the department and fishermen takes place continuously over long periods of time. The process of communication work out a closer cooperative, Fisheries Department and the fishermen are equally responsible for the impact and effectiveness of communication that occurs.

The nearness of the relationship between Fisheries Department and the fishermen is not only formal, even they are already at the informal stage. Various problems experienced by fishermen are always consulted to Fisheries Department. This pattern of relationships can occur because of the openness between department and fishermen, so they have a common goal. Various opportunities to improve the economy and competitiveness of fishermen be delivered from department to the fishermen.

In transactional communication model, each communications actors in this case Pandeglang District Fishery Departement and traditional fisherman group equally build the similarity of meaning that is improving the economy and competitiveness of fishermen. Various strategies undertaken by the fisheries department are done so that fishermen out of poorness, and they have a high competitiveness to fishermen from outside Pandeglang District. Their communication process is very influenced by past experiences. Fishermen want to get out of economic difficulties soon. Fisheries Department in this case the Head of Fisheries sought to help fishermen by using his experience while serving in the Office of Cooperatives. This past experience is a strength for both parties to keep in good communication currently.

This transactional communication model encourages us to understand that the messages created between the Fisheries Department and fishermen influence each other. A message is constructed from the previous message so that there is an interdependence between each communication component. Changes in local government policy or attitude change from fishermen will change the others. The process of communication that they intertwine takes place continuously both verbally and non verbally.

Fisheries Department in carrying out its function has a partner i.e the buyer of the catch of fishermen or commonly called bakulan / langgan. Communication model formed is interactional. In every communication activity that occurs the process of delivering two-way messages, Fisheries Department to partners and otherwise. In the interactional communication model, feedback is a very important thing. Any policy applied by the fisheries department will give rise to reaction or feedback from partners. Similarly, communication between fishermen and their partners. The interdependence between fishermen and partners makes the fishermen do not have a strong bargaining position on the catch. This becomes a reaction that arises from the exchange of messages the others.

\section{CONCLUSION}

Based on the research results, it can be concluded that the local government of Pandeglang District has various strategies to improve the competitiveness of fishermen. The Pandeglang District Fishery Department carry out their role by encouraging the formation of cooperative fishermen groups. It aims to enable the fishermen in groups to help each other to improve their economy so that in the future they have bargaining power over their catch.

Transactional communication model formed between local government in this case Pandeglang District Fishery Department with fishermen either individually or in groups. While interactional communication model formed between local government with partners, and between fishermen with partners.

\section{REFERENCES}

Burgoon, Michael, Michael Ruffner, 1978, Human Communication A Revision of Approaching 
Speech/Communication, New York: Holt, Rinehart \& Winston

Carter, J. R and Price, P. M. 1993. Integrated Materials Management (London:Pitman)

Chen and Paulraj. 2004. Understanding supply chain management: Crritical research and a theorithical framework. Int Journal of Production Research. Vol 42 No 1. p. 131-163. DOI: 10.1080/00207540310001602865.

Cota, A.A., Evans,C.R., Dion,K.L., Kihk,L., Longman,R.,1995, The Structure of Group Cohesion, Personality and Social Psychology Bulletin, vol. 21, pp. 572-580

Dale , B. G., Lascelle, D. M and Lloyd, A. 1994. Supply chain management and development. In B.G. Dale (ed), Managing Quality (London: Prentice-Hall), p. 292-315

Guba, E.G., 1990, The Alternative Paradigm Dialog dalam E.G. Guba (Ed.) The Paradigm Dialog,

Newbury Park, CA: Sage, halaman 17-30

Heckert, J.B and Miner, R. B. 1940. Distribution Costs (New York: Ronald)

Imron, Masyhuri, 2003, Poverty in Fishermen Society, Society and Culture Journal, Volume 5 No. 1, halaman 63-84

Kebijakan Pemerintah Terkait Nelayan Tradisional. www. kompas. com [10 April 2017]

Lascelles, D. M. And Dale, B. G. 1989. The Buyer- Supplier Relationship in Total QualityManagement. Journal of Purchasing and Materials Management. p. 10-19

Lewis. 1956. The Role of Air Freight in Physical Distribution (Boston: Graduate School of Business Administration, Division of Research, Harvard University)

Government Regulation Nomor 50 / 2015 about Empowerment of Small Fishermen and Small Fishers

Robbin, Stephen P. dan Judge, Timothy A., 2007, Organizational Behavior, 12th ed., New Jersey, Pearson Education, Inc.

Sarwono, Sarlito Wirawan, (2005), Social Psychology: Group Psychology and Psychology Applied $3^{\text {th }}$ edition, Jakarta, Balai Pustaka

Sendjaja, Sasa Djuarsa, 2011Communication Theory, Jakarta, Penerbit Universitas Terbuka

Tönnies, F, 1957, Community and Society. Courier Dover Publications.

Tzanatos, Evangelos et.all , 2006, Principal socio-economic characteristics of the Greek smallscale coastal fishermen, Ocean \& Coastal Management 49, pp. 511-527

Watson, W. E., Doster, J., \& Michaelsen, L. K.,1990, Individual and group meaning: Exploring the reciprocal relation, International Journal of Personal Construct Psychology, 3(2), 231-248 